\title{
1. Introduction to The Legal Limits of Direct Democracy
}

\section{Daniel Moeckli}

\section{CONTEXT}

Direct democracy is on the rise. Recent years have seen a mushrooming of direct-democratic mechanisms such as citizens' initiatives and referendums all over the world. ${ }^{1}$ Beyond Switzerland and some US states, where direct democracy already has a long tradition, more and more states, especially in Europe, have started to introduce various forms of direct-democratic participation. Out of the 47 member states of the Council of Europe, $27 \mathrm{know}$, at the national level, the law-initiated referendum (here defined as a referendum that is triggered if certain conditions specified by law are met), 30 the legislature-initiated referendum (defined as a referendum that can be initiated by parliament (or parts of it)), 20 the executive-initiated referendum (defined as a referendum that can be initiated by government (or parts of it)) and five the subnational entity-initiated referendum (defined as a referendum that can be initiated by (a certain number of) subnational entities such as regions or provinces). Twenty-one Council of Europe member states provide for a proactive citizens' initiative (defined as an instrument that allows a certain number of citizens to initiate a referendum and formulate the topic of the referendum), a further eight for a rejective citizens' initiative (defined as an instrument that allows a certain number of citizens to initiate a referendum that is aimed at preventing new laws (or parts of them) from being passed or at repealing existing laws (or parts of them)) and 28 for an agenda initiative (defined as an instrument that allows a certain number of citizens to put an issue on the agenda of state organs but that does not lead to a referendum). ${ }^{2}$

1 See for example Matt Qvortrup (ed.), Referendums Around the World: The Continued Growth of Direct Democracy (Palgrave Macmillan 2014).

2 See the database of the project 'Popular Sovereignty vs. the Rule of Law? Defining the Limits of Direct Democracy' (LIDD), lidd-project.org/data, accessed 30 November 2020. 
Use of these instruments is increasing: in 2006, 18 referendums were held in European countries; by 2016, this number had risen to $58 .^{3}$ Even states with hardly any direct-democratic experience, such as the Netherlands and the United Kingdom, have recently started to hold referendums. ${ }^{4}$ In addition, in numerous countries direct-democratic instruments exist at the regional or municipal level. With the introduction of the European Citizens' Initiative (ECI) in 2012, direct democracy now even applies at the supranational level. Importantly, as for example the Brexit vote illustrates, not only are referendums typically reserved for deciding the most fundamental issues, but also are their results, even when not legally binding, assigned a special legitimacy and finality. ${ }^{5}$

One consequence of the increase in direct-democratic participation is that, more and more often, citizens propose measures, or are called to vote on measures, which are problematic from the perspective of the rule of law - be it because the proposed measure clashes with international legal obligations or human rights guarantees, be it because the process leading up to the vote does not conform to rule-of-law requirements. ${ }^{6}$ In Switzerland, popular votes were

3 See the 'Datenbank und Suchmaschine für direkte Demokratie', www.sudd .ch , accessed 14 August 2020. See also Laurence Morel, 'Referendum', in Michel Rosenfeld and Andras Sajó (eds), The Oxford Handbook of Comparative Constitutional Law (OUP 2012) 501, 513-514.

4 On 6 April 2016, the Netherlands held its first referendum under the Advisory Referendum Act of 2015 on the Association Agreement between the EU and Ukraine. See Kiesraad (Electoral Council), 'Results of the referendum on the Association Agreement with Ukraine', 12 April 2016, https:/english.kiesraad.nl/latest- news/ news/2016/04/12/results-of-the-referendum-on-the-association-agreement-with-th e-ukraine accessed 14 August 2020. On 23 June 2016, the United Kingdom held a referendum on the United Kingdom's membership of the European Union. See Electoral Commission, 'EU Referendum Results', available at http://www.electoralcommission .org.uk/find-information-by-subject/elections-and-referendums/past-elections-and -referendums/eu-referendum/electorate-and-count-information accessed 14 August 2020.

Although the United Kingdom European Union membership referendum is not legally binding, there was never a real prospect of government or parliament ignoring it, as is exemplified by then Prime Minister Theresa May's famous mantra 'Brexit means Brexit'. See, e.g., Michael Wilkinson, 'No Brexit until 2022? Philip Hammond Warns EU Exit Could Take at Least Four Years', The Telegraph, 12 July 2016.

6 While the rule of law has been given different meanings at different moments in time and in different legal traditions, there is broad consensus today with regard to its most fundamental elements. According to the Venice Commission of the Council of Europe, these core elements include legality, legal certainty, prohibition of arbitrariness, access to justice before independent and impartial courts, respect for human rights and equality before the law. See Rule of Law Checklist, adopted by the Venice Commission at its 106th Plenary Session (Venice, 11-12 March 2016), 
held on a ban on the construction of minarets ${ }^{7}$ and immigration restrictions that violate international treaties, ${ }^{8}$ to name just two examples. In Croatia, a citizens' initiative suggested restricting the use of minority languages. ${ }^{9}$ In Ireland and Liechtenstein, voters decided that abortion should constitute a criminal offence. ${ }^{10}$ In Hungary, a citizens' initiative demanded the reintroduction of the death penalty, ${ }^{11}$ while in a government-initiated referendum the electorate decided that any refugee quotas imposed by the European Union (EU) should be rejected. ${ }^{12}$ In Croatia, Slovakia and Slovenia, majorities of voters decided to deny same-sex couples the right to marry. ${ }^{13}$ In the United Kingdom, the electorate was asked to decide on Brexit without knowing the exact legal consequence of the referendum, violating, it has been argued, the requirement of transparency inherent in the rule of law. ${ }^{14}$ At the level of the EU, in December 2015, the ECI 'Mum, Dad \& Kids' was registered, demanding 'marriage' to be

CDL-AD(2016)007, 7. Importantly for our purposes, the principle of legality requires any state action to be in accordance with the law, including international law, and establishes certain requirements with regard to the law-making procedure, such as the principle of transparency. Ibid., 11-13.

7 Bundesratsbeschluss über das Ergebnis der Volksabstimmung vom 29. November 2009, Bundesblatt 2010, 3437.

8 Bundesratsbeschluss über das Ergebnis der Volksabstimmung vom 9. Februar 2014, Bundesblatt 2014, 4117.

9 'Croatia's Constitutional Court Says No to Cyrillic Referendum', Croatia Week, 12 August 2014, http://www.croatiaweek.com/croatias-constitutional-court-says-no-to -cyrillic-referendum/ accessed 14 August 2020.

10 Department of the Environment, Community and Local Government, Referendum Results 1937-2015 (2015), 70-71; Regierungskanzlei, Ergebnis der Volksabstimmung vom 16./18. September 2011 über das Initiativbegehren zur Abänderung des Strafgesetzbuches (Hilfe statt Strafe), http://www.llv.li/\#/1156/abstimmungsergebnisse accessed 14 August 2020.

11 National Election Commission, Decision 99/2015 of 27 May 2015, http:// valasztas.hu/hu/nvb/ hatarozatok/2015/2015-5673.html accessed 14 August 2020.

12 Since the required turnout quorum was not reached, the referendum result is not legally binding. National Election Commission, 'National Referendum of 2 October 2016: Data Relating to the Result of the National Referendum', http://www.nvi.hu/en/ ref2016/481/481_0_index.html accessed 14 August 2020.

13 State Election Commission of the Republic of Croatia, Results of the National Referendum of 1 January 2013, http://www.izbori.hr/2013Referendum/rezult/rezultati .html accessed 14 August 2020; Statistical Office of the Slovak Republic, Final Results of the Referendum of 7 February 2015, http://volby.statistics.sk/ref/ref2015/en/tab01 .html accessed 14 August 2020; 'Slovenians vote against same-sex marriage in referendum', The Guardian, 21 December 2015.

${ }_{14}$ The argument that the Brexit referendum violated the rule of law has been advanced most prominently by Philip Allott, 'Forget the politics - Brexit may be unlawful', The Guardian, 30 June 2016. 
defined as a union between a man and a woman and 'family' as being based on marriage and/or descent..$^{15}$

These and similar referendums and initiatives have triggered vigorous political debates in the respective countries: should there be any limits as to what the people are allowed to propose or vote on? Who should decide what is permissible and what is not? The question of the relationship between popular sovereignty and rule-of-law principles is set to gain heightened importance throughout Europe: on the one hand, the body of international law that restricts the scope of decision-making at the national level continues to grow. On the other hand, especially 'populist' movements make increasing use of direct-democratic instruments to promote divisive measures that clash with the rule of law. ${ }^{16}$

Despite their great relevance for the future of democracy in Europe, these issues have remained almost completely unexplored. While there are a number of very useful books dealing with direct democracy and referendums in general, ${ }^{17}$ none of these books, which have all been written by political scientists, addresses the question as to the legal limits of direct democracy in a meaningful way. Some authors have dealt with the relationship between direct democracy and the rule of law from a rather general or theoretical perspective, ${ }^{18}$ others have explored conflicts between specific direct-democratic instruments and international (or national) law in the context of particular jurisdictions (notably the United States, ${ }^{19}$ France $^{20}$ and Switzerland $\left.{ }^{21}\right)$. However, a comprehensive legal assessment of the limits of direct democracy or of systems of reviewing

15 European Commission, Official Register of ECIs, http://ec.europa.eu/citizens -initiative/public/ initiatives/open/details/2015/000006 accessed 14 August 2020.

16 On populism, see, e.g., Jan-Werner Müller, What is Populism? (University of Pennsylvania Press 2016).

17 Laurence Morel, La question du référendum (Presses de Sciences Po 2019); Laurence Morel and Matt Qvortrup (eds), The Routledge Handbook to Referendums and Direct Democracy (Routledge 2018); Matt Qvortrup (ed.), Referendums Around the World: The Continued Growth of Direct Democracy (Palgrave Macmillan 2014).

18 E.g. Wilfried Marxer (ed.), Direct Democracy and Minorities (Springer 2012); Anna Christmann, Die Grenzen direkter Demokratie: Volksentscheide im Spannungsverhältnis von Demokratie und Rechtsstaat (Nomos 2012).

19 Shaun Bowler, 'When Is It OK to Limit Direct Democracy?' (2013) 97 Minnesota Law Review 1780; Kenneth P. Miller, Direct Democracy and the Courts (CUP 2009); Eric Lane, 'Men Are Not Angels: The Realpolitik of Direct Democracy and What We Can Do about It' (1998) 34 Willamette Law Review 579.

20 Marthe Fatin-Rouge Stéfanini, Le contrôle du référendum par la justice constitutionelle (Economica 2004).

21 Guillaume Lammers, La démocratie directe et le droit international (Stämpfli 2015); Roger Nobs, Volksinitiative und Völkerrecht (Dike 2006). 
these limits does not exist. This book aims at providing the foundations for addressing these gaps.

\section{QUESTIONS EXPLORED}

All members of the Council of Europe have committed themselves to the fundamental values enshrined in its Statute, namely democracy, the rule of law and human rights. ${ }^{22}$ These values are also codified in Article 2 of the Treaty on European Union (TEU). ${ }^{23}$ Thus, the normative premise for all European states is that they must strive to realise all of these values at the same time, that none of them can take absolute priority over the others. If popular sovereignty, on the one hand, and the rule of law and human rights, on the other, come into conflict, an appropriate balance must be struck between them.

Yet how exactly should this be done? And how is it, in fact, done in practice? There is only one document that sets forth international standards for the use of direct-democratic instruments: the Code of Good Practice on Referendums (since October 2020 called Revised Guidelines on the Holding of Referendums) of the Venice Commission of the Council of Europe. ${ }^{24}$ Part I of the book deals with this unique document. Chapter 2 gives an overview of the Code's relevance, contents and use. The Venice Commission was, at the time of writing of this book, in the process of revising the Code. Therefore, Chapter 3 explains the general thinking behind this process of revision, which was completed in October 2020.

The Code is a soft-law instrument, meaning that it is, as such, not legally binding. This raises the crucial question of whether its standards are grounded in state practice. To what extent do they reflect the laws and the practice of European states?

To answer this question, it is necessary to zoom in on the national level. Parts II and III therefore offer an in-depth analysis of the limits imposed on direct-democratic instruments and of systems of reviewing compliance with these limits in selected European states. Experts from 11 European countries were invited to draft reports that address a uniform list of approximately 20

\footnotetext{
22 See Statute of the Council of Europe, ETS No. 001, Preamble, para. 3.

23 Treaty on European Union (TEU), OJ 2016/C 202/01.

24 Code of Good Practice on Referendums, adopted by the Council for Democratic Elections at its 19th meeting (Venice, 16 December 2006) and the Venice Commission at its 70th plenary session (Venice, 16-17 March 2007), CDL-AD (2007) 008rev; Revised Guidelines on the Holding of Referendums, approved by the Council of Democratic Elections at its 69th online meeting (7 October 2020) and adopted by the Venice Commission at its 124th online Plenary Session (8-9 October 2020), CDL-AD(2020)031.
} 
questions for 'their' country. The questions revolved around the following basic issues:

1. What type of direct-democratic instruments exist in the country concerned? For the purposes of this study, we distinguish between the following types of instruments:

- law-initiated referendum (often also called 'mandatory referendum'): a referendum that is triggered if certain conditions specified by law are met;

- institution-initiated referendum: a referendum that can be triggered by the legislature (or parts of it), the executive (or parts of it) or (a certain number of) subnational entities;

- citizen-initiated referendum (citizens' or popular initiative): an instrument that allows a certain number of citizens to initiate a referendum and formulate its topic (proactive initiative) or to initiate a referendum that is aimed at preventing a constitutional or legislative amendment from being passed or at abolishing it (rejective initiative);

- citizens' agenda initiative: an instrument that allows a certain number of citizens to put an issue on the agenda of state organs but that does not lead to a referendum.

2. What are the legal limits that apply with regard to these instruments?

- Substantive limits preclude referendums and citizens' initiatives on certain subject matters. Prohibited subject matters may, for example, include constitutional amendments, proposals that violate international law or fundamental rights, state finances, emergency powers, pardons and amnesties, etc.

- Formal limits are designed to ensure that the will of the people is formed in a way that conforms to the rule of law by imposing certain requirements regarding the formulation of the referendum question. These requirements may include, for example, that the referendum question (or the initiative proposal) must be clear and precise, must only address one subject matter (unity of substance requirement) or may not mix different normative levels or different direct-democratic instruments (unity of form requirement). 
3. What type of institution is in charge of reviewing compliance with these limits and how is the review procedure designed?

- Is it the constitutional court, some other court, the parliament, a governmental authority, an election commission or some local authority that decides whether a referendum or an initiative complies with the limits? What exactly is the institutional position of this body, especially in terms of its independence?

- How is the review procedure designed? For example, when does the review take place (in the case of initiatives, for instance, before or after the collection of signatures)? Who can participate in the proceedings? Which due process guarantees apply? Is there a legal remedy against the decision on the admissibility of a referendum or an initiative? Who decides on the claim for remedy? What are the legal consequences in case of inadmissibility?

Most of the resulting country reports were presented and discussed, together with the contributions on the Venice Commission's Code, at a workshop that was held at the University of Zurich on 28 February 2020 and attended by leading experts on direct democracy. The feedback received at this workshop helped the authors further refine and improve their contributions and ensured that the key issues are addressed consistently throughout them. The resulting country analyses form the bulk of the book.

The conclusion provides a comparative analysis of the situation in the selected states, drawing out key commonalities and differences, as well as an assessment of the law and the practice at the national level when judged against the international standards contained in the Venice Commission's Guidelines on the Holding of Referendums.

\section{COUNTRY SELECTION}

The 11 European states that are covered in Parts II and III were selected because their legal frameworks of direct-democratic instruments and their direct-democratic practice are particularly interesting and relevant with regard to the research questions explored in this book. First, all of these states have a rather elaborate system of direct-democratic instruments and/or a rich practice of using such instruments. Liechtenstein and Slovakia, for example, are the states with the largest arsenal of direct-democratic instruments in Europe: they both have six out of the seven types of instruments that exist. Even the states with the lowest number of instruments, France and Hungary, still have three - and, moreover, an interesting and relevant direct-democratic practice. Second, all selected states constitute paradigmatic cases in that they impose 
specific types of legal limits on their direct-democratic instruments and/or use particular institutional and procedural systems of reviewing compliance with these limits.

Furthermore, we tried to achieve an even geographical distribution between, on the one hand, Western European countries or 'old' democracies (Switzerland, Liechtenstein, Italy, Spain, France) and, on the other, Eastern European countries or 'new' democracies (Slovenia, Croatia, Slovakia, Hungary, Latvia, Russia). Finally, a conscious effort was made to include states that, at least in the English-speaking literature, are hardly ever covered in this context (for example Russia, Slovakia, Latvia, Liechtenstein). As a result, the book also offers insights into the functioning of direct-democratic systems that are largely unknown in wide parts of the world.

With regard to 'old' democracies, Switzerland (Chapter 4) is an obvious choice because it is the state with the longest history of direct democracy and one that values popular sovereignty particularly highly. Liechtenstein (Chapter 5) may be a small state, but it has, as mentioned above, a sophisticated system of direct-democratic instruments and has conducted more than 100 referendums at the national level. Italy (Chapter 6) is a prototypical case of a parliamentary democracy that is complemented with a well-established system of specific direct-democratic instruments. The case law of the Italian Constitutional Court dealing with the abrogative referendum provides a particularly fruitful source of information for the purposes of the present inquiry. In Spain (Chapter 7), the representative system has undergone a crisis in recent years, causing direct-democratic instruments to take on an unprecedented role. Although in France (Chapter 8) referendum practice is scarce, it makes for an interesting case as the President can trigger referendums and is subject to hardly any legal requirements when doing so.

As far as 'new' democracies are concerned, Slovenia (Chapter 9) has a well-developed system of direct-democratic instruments as well as a quite rich practice of holding referendums. In addition, Slovene case law regarding the legal review of direct-democratic instruments offers some interesting insights. Croatia (Chapter 10) equally provides for a range of instruments of direct democracy, including the proactive citizens' initiative. However, the Constitutional Court applies a very stringent test to review the constitutionality of popular initiatives. Slovakia (Chapter 11) has no fewer than six direct-democratic instruments. Nevertheless, the promise to involve the people directly in decision-making has been largely unfulfilled as the signature threshold for initiatives and the turnout quorum for referendums are extremely high and referendum results need to be implemented by parliament. In Hungary (Chapter 12), an elaborate system of substantive and formal limits is imposed on direct-democratic instruments, coupled with a rigorous authorisation procedure. As a result, less than 10 per cent of the over 2,000 initiatives 
for a referendum launched by Hungarian citizens or institutions have been able to survive the admissibility procedures of the election commission and the supreme court. Latvia (Chapter 13) also has a sophisticated system of direct-democratic instruments, of which the agenda initiative and the proactive citizens' initiative are those used most often. While only few limits are imposed on the former, the latter is restricted by a range of open-ended substantive and formal legal limits. In Russia (Chapter 14), finally, the constitution grants the referendum an important status, but its practical relevance is, at least at the national level, very limited. This contrast can be explained by the strong legal limits imposed on the referendum by the legislator and the restrictive practice of Russian courts in the remedy procedures. 